\title{
Management of coping with the risks of COVID-19 in an onco- hematological outpatient clinic: an experience report
}

\author{
Gestão do enfrentamento dos riscos da COVID-19 em uma rede ambulatorial onco-hematológica: relato de experiência
}

Gestión del afrontamiento de los riesgos de COVID-19 en una red oncohematológica ambulatoria: relato de experiencia

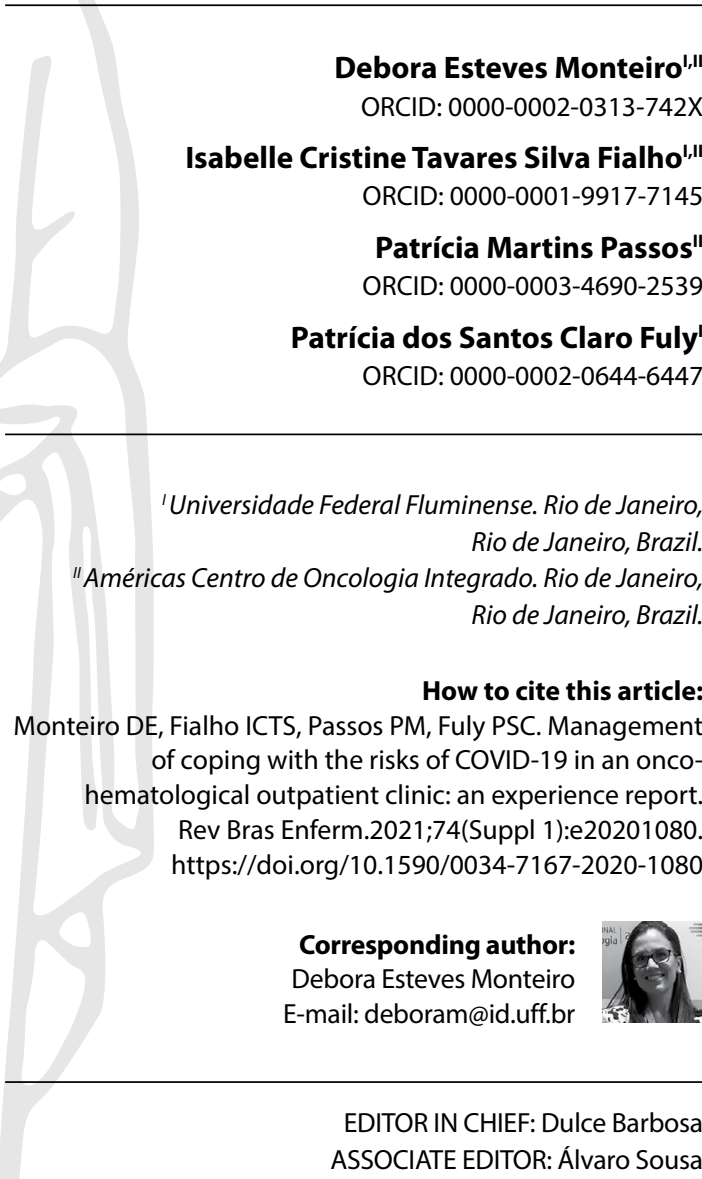

Submission: 09-19-2020
Approval: 12-30-2020

\section{ABSTRACT}

Objective: to describe the experience of a private outpatient network for hematology and oncology treatment in the adoption of management tools to face the risk of contamination by SARS-CoV-2. Method: an experience report on the use of a root cause analysis method to identify potential risks of contamination by COVID-19 among patients and employees. Through the risks identified through the Ishikawa Diagram, we built an action plan, linked to the $5 \mathrm{~W} 2 \mathrm{H}$ tool, for planning and decision-making implemented. Results: the number of attendances in person and people circulating in the units was reduced, protective distance measures and new protection barriers were fundamental to control the risks of spreading COVID-19 in patients and employees. Final considerations: the management tools served as a valuable tool in the construction of measures, making the measures in question more clearly and applicable.

Descriptors: Coronavirus; Medical Oncology; Health Services Administration; Occupation Health; Pandemics.

\section{RESUMO}

Objetivo: descrever a experiência de uma rede ambulatorial privada de tratamento onco-hematológico na adoção de ferramentas de gestão para o enfrentamento do risco de contaminação por SARS-CoV-2. Método: relato de experiência acerca do uso de um método de análise de causa-raiz para a identificação de potenciais riscos de contaminação pela COVID-19 entre pacientes e colaboradores. Através dos riscos identificados por meio do Diagrama de Ishikawa, construímos um plano de ações, articulado à ferramenta $5 \mathrm{~W} 2 \mathrm{H}$, para um planejamento e tomada de decisões implementadas. Resultados: foi reduzido o quantitativo de atendimentos presencias e de pessoas circulantes nas unidades, medidas protetivas de distanciamento e novas barreiras de proteção foram fundamentais ao controle dos riscos de disseminação da COVID-19 em pacientes e colaboradores. Considerações finais: as ferramentas de gestão serviram como instrumento de grande valia na construção das medidas, viabilizando com maior clareza e aplicabilidade as medidas colocadas em questão. Descritores: Coronavirus; Oncologia; Administração de Serviços de Saúde; Saúde do Trabalhador; Pandemias.

\section{RESUMEN}

Objetivo: describir la experiencia de una red privada ambulatoria de tratamiento oncohematológico en la adopción de herramientas de manejo para enfrentar el riesgo de contaminación por SARS-CoV-2. Método: informe de experiencia sobre el uso de un método de análisis de causa raíz para identificar riesgos potenciales de contaminación por COVID-19 entre pacientes y empleados. A través de los riesgos identificados a través del Diagrama de Ishikawa, construimos un plan de acción, vinculado a la herramienta $5 \mathrm{~W} 2 \mathrm{H}$, para planificar y tomar decisiones implementadas. Resultados: se redujo el número de asistencia presencial y de personas circulantes en las unidades, las medidas de protección a distancia y nuevas barreras de protección fueron fundamentales para controlar los riesgos de diseminación del COVID-19 en pacientes y colaboradores. Consideraciones finales: las herramientas de gestión sirvieron como una valiosa herramienta en la construcción de las medidas, haciendo que las medidas en cuestión sean más claras y aplicables.

Descriptores: Coronavirus; Oncología Médica; Administracion de los Servicios de Salud; Salud Laboral; Pandemias. 


\section{INTRODUCTION}

The World Health Organization (WHO), on March 11, 2020, declared the public health emergency by COVID-19 as a pandemic, due to the threat of its simultaneous spread worldwide. In Brazil, the Ministry of Health $(\mathrm{MoH})$ confirmed the cases of community transmission on March 13th. From that date, measures to contain the disease were being published and the first state decrees appeared, regulating criteria of social isolation and quarantine related to COVID-19(1).

Cancer therapy requires close monitoring, considering the need for patient monitoring and immunosuppressive treatment, with chemotherapy and radiotherapy. This implies a high risk of contagion and worsening by COVID-19, since they constitute a population group more vulnerable to infection by SARS-CoV-2, when compared to non-cancer patients ${ }^{(2)}$.

Considering the potential for transmission of COVID-19 by aerosols, droplets or close contact, and the risk of transmission being aggravated in agglomerations, the early identification of COVID-19 in onco-hematological patients, as well as the understanding of its distribution characteristics, may contribute to controlling the spread of SARS-CoV-2 and increasing the cure rate ${ }^{(3)}$.

Faced with an unprecedented scenario full of challenges for COVID-19 prevention, such as adaptation of health teams and patients to new routines and daily care, uncertainties regarding the effectiveness of treatments and fear of illness and death, the needs to develop actions were identified, aiming at greater safety for patients who need cancer care and also for professionals who work on the front line in care during the pandemic.

\section{OBJECTIVES}

To describe the experience of a private outpatient network for hematology and oncology treatment in the adoption of management tools to face the risk of contamination by SARS-CoV- 2 .

\section{METHODS}

This is an experience report on the implementation of the root cause analysis method using its own tool, the Ishikawa Diagram, for the identification of potential contamination risks inherent to COVID-19 among patients and collaborators in a private outpatient hematology and oncology treatment. The same was implemented through the following steps: organization of the multidisciplinary team, recognition and detailed description of the SARS-CoV-2 contamination event, and determination of possible causes and their effects.

According to Mello 2017, the Cause-and-Effect Diagram, also known as the Ishikawa Diagram, can be used to find probable causes that contribute to an effect or event. Its applications are to allow the team to identify, explore and demonstrate through graphics possible factors, causes related to a problem or condition effect. The Ishikawa Diagram can be used to investigate a negative effect and correct it, or a positive effect, incorporating it into the process. When identifying the company's problem, looking for the cause that caused it, an analysis of the process in question is carried out ${ }^{(4)}$.

In order to face the identified risks, an action plan was built articulated with the $5 \mathrm{~W} 2 \mathrm{H}$ tool, which was implemented in the units for an analysis of risk reduction. The $5 \mathrm{~W} 2 \mathrm{H}$ tool is an action plan that aims to execute a checklist aiming at the accuracy of the results for planning and decision-making regarding the actions that must be implemented ${ }^{(4)}$. The tool works according to the following Chart 1.

Chart $1-5 W 2 \mathrm{H}$ method tool

\begin{tabular}{|l|l|l|l|}
\hline \multicolumn{2}{|l}{$\mathbf{5}$ W 2 H Method } \\
\hline \multirow{5}{*}{$5 \mathrm{~W}$} & What & O que? & What action will be taken? \\
\cline { 2 - 4 } & Who & Quem? & Who will execute/participate in the action? \\
\cline { 2 - 4 } & Where & Onde? & Where will the action be carried out? \\
\cline { 2 - 4 } & when & Quando? & When will the action be performed? \\
\cline { 2 - 4 } & Why & Por quê? & Why will it be executed? \\
\hline \multirow{2}{*}{$2 \mathrm{H}$} & How & Como? & How will the action be performed? \\
\cline { 2 - 4 } & How Much & Quanto custa? & $\begin{array}{l}\text { How much does it cost to perform the } \\
\text { action? }\end{array}$ \\
\hline
\end{tabular}

Source: Mello $2017^{(4)}$

This report was based on the experience of nursing managers in coping with the COVID-19 pandemic through measures implemented, in a time frame from March to June 2020, in order to preserve the health of hematology and oncology patients and professionals who work in the institution. The multidisciplinary health team and administrative employees were involved in the actions implemented ${ }^{(6)}$.

The management experience was implemented in 7 outpatient units of chemotherapy, radiotherapy and multidisciplinary hematological and oncological consultations, located in the state of Rio de Janeiro.

Such measures were motivated by the vulnerability and fragility of these patients and the teams that work in an outpatient chemotherapy scenario, especially those in risk groups, amidst the pandemic. They were supported by recommendations from $\mathrm{WHO}, \mathrm{MoH}$ and recommendations for the management of cancer patients in the pandemic.

\section{RESULTS}

In order to adapt the defendants to the resolutions of the $\mathrm{MoH}$ and the Pan American Health Organization (PAHO), and especially to minimize the risk of contamination, there was a need to build a Cause-and-Effect Diagram, with the critical points on which we are based to decision-making through the $5 \mathrm{~W} 2 \mathrm{H}$ management tool, illustrated by Figure 1 .

With the possible causes mapped through the constructed diagram, the managers created the measures in order that these would have a possible impact in reducing the possibility of contamination, which is the main issue that causes us concern. The measures were placed in spreadsheets using the $5 \mathrm{~W} 2 \mathrm{H}$ tool so that these spreadsheets became a facilitating instrument for the viability of measures and decision-making. The tool works according to the following Chart 2.

Through these actions, the number of on-site visits to patients at the units was reduced, without their flow of monitoring being reduced. The reduced number of people circulating in the units, associated with protective distance measures and new protection barriers, were fundamental to control the risks of dissemination of COVID-19. 


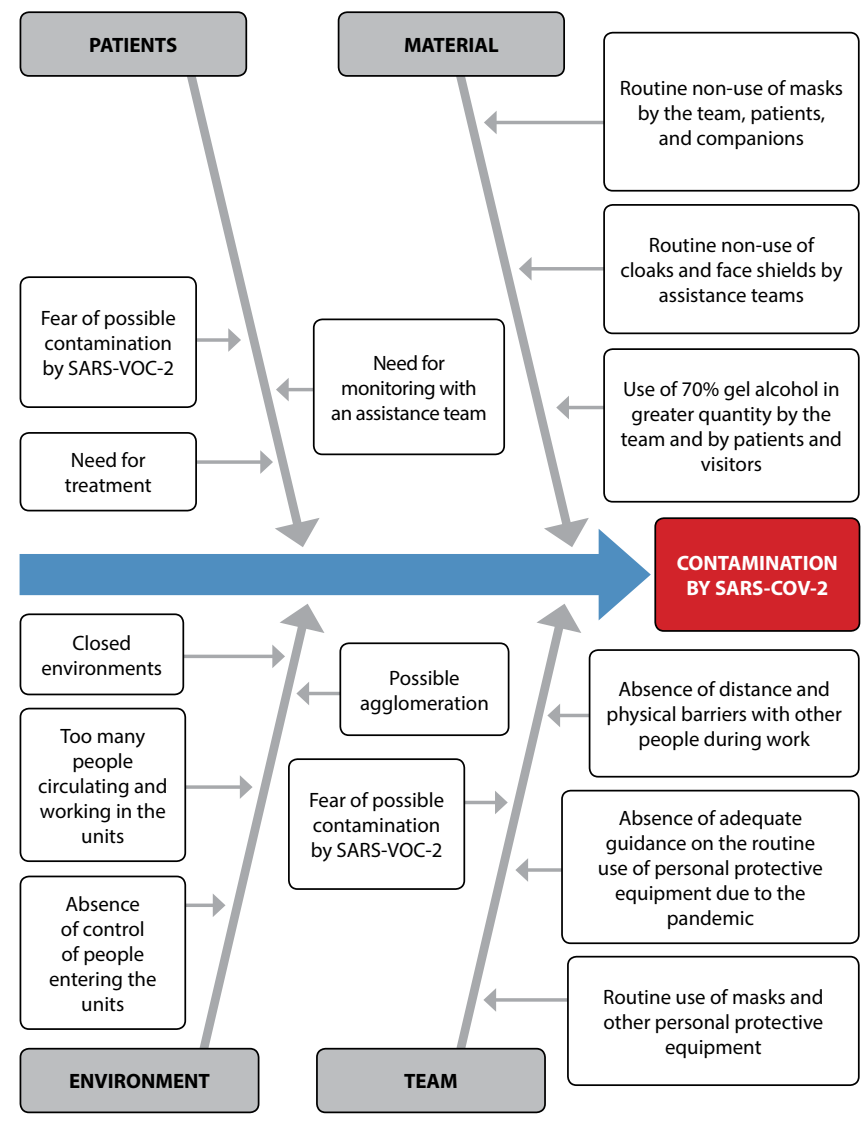

Figure 1 - Diagram of cause and effect constructed based on the critical points, Rio de Janeiro, Rio de Janeiro, Brazil, 2020

\section{DISCUSSION}

Among the preventive measures for SARS-CoV-2, there are those of a non-pharmacological nature, already widespread, that help in the process as: washing hands frequently with soap and water for at least 20 seconds, and if there is no soap and water, use a $70 \%$ alcoholbased disinfectant; avoiding touching the eyes, nose and mouth with unwashed hands; physical distance, avoiding close contact with sick people; home isolation in case of confirmed diagnosis; covering the mouth and nose, with a tissue, in episodes of coughing and/or sneezing; disinfecting frequently touched objects and surfaces ${ }^{(1)}$.

Using masks is also part of the prevention and control measures, recommended to contain the spread of certain viral respiratory diseases, including COVID-19. They can be used to protect healthy individuals (when in contact with someone infected) or to control the source (when used by someone infected to prevent further transmission). Its universal use in health services is defined as the requirement by all health workers and by anyone within the enclosure, regardless of the activities performed ${ }^{(5)}$.

As for contact precautions and droplets, include wearing an apron, gloves and eye protection ${ }^{(5)}$. In infusion sectors, where chemotherapy treatments are carried out, professionals are advised, even before the pandemic, on the use of long-sleeved waterproof cloaks with elastic cuffs, $\mathrm{N}-95$ masks and safety glasses. A change in the routine of these professionals was regarding the mandatory use of face shield not only during the administration of medications, but at all times during assistance. As recommended by Anvisa, the use of N95/PFF2 mask or equivalent contact with the droplets expelled by the patient was maintained, minimizing mask contamination ${ }^{(7)}$.

Chart 2 - 5W2H action plan built based on evidence shown in the Cause-effect diagram, Rio de Janeiro, Rio de Janeiro, Brazil, 2020

\begin{tabular}{|c|c|c|c|c|c|}
\hline What? & Who? & Where? & Why? & How? & How much? \\
\hline $\begin{array}{l}\text { Make sure that } \\
\text { only those who } \\
\text { really need it with } \\
\text { minimal or no } \\
\text { companions come } \\
\text { to the clinic. }\end{array}$ & $\begin{array}{l}\text { Call center staff for } \\
\text { confirmation of } \\
\text { treatment consultation. }\end{array}$ & $\begin{array}{l}\text { During consultation } \\
\text { and treatment } \\
\text { confirmation call } \\
\text { that is performed } \\
\text { previously }\end{array}$ & $\begin{array}{l}\text { So that the number of } \\
\text { people in the clinic is } \\
\text { reduced. }\end{array}$ & $\begin{array}{l}\text { During the call, the attendant } \\
\text { will inform that patients will } \\
\text { only come with a companion if } \\
\text { they need it. }\end{array}$ & $\begin{array}{l}\text { Absence of } \\
\text { additional cost. }\end{array}$ \\
\hline Pre-screening. & $\begin{array}{l}\text { Call center staff for } \\
\text { confirmation of } \\
\text { treatment consultation. }\end{array}$ & $\begin{array}{l}\text { During consultation } \\
\text { confirmation and } \\
\text { treatment call that is } \\
\text { performed previously. }\end{array}$ & $\begin{array}{l}\text { So that the number of } \\
\text { people with symptoms } \\
\text { of COVID } 19 \text { in the units } \\
\text { is reduced. }\end{array}$ & $\begin{array}{l}\text { During the call, the attendant } \\
\text { will inform you that the patient } \\
\text { should not come to the unit if } \\
\text { he is symptomatic. }\end{array}$ & $\begin{array}{l}\text { Absence of } \\
\text { additional cost. }\end{array}$ \\
\hline $\begin{array}{l}\text { Consultations } \\
\text { carried out by } \\
\text { telemedicine and/ } \\
\text { or telephone. }\end{array}$ & $\begin{array}{l}\text { Medical and } \\
\text { multidisciplinary team }\end{array}$ & $\begin{array}{l}\text { At the institution, } \\
\text { through computers } \\
\text { and institutional } \\
\text { phones. }\end{array}$ & $\begin{array}{l}\text { So that these patients } \\
\text { and their companions } \\
\text { do not need to attend } \\
\text { the consultation in } \\
\text { person. }\end{array}$ & $\begin{array}{l}\text { Making phone calls or video } \\
\text { calls at previously scheduled } \\
\text { times. }\end{array}$ & $\begin{array}{l}\text { Absence of } \\
\text { additional cost. }\end{array}$ \\
\hline Screening. & Nursing technician. & $\begin{array}{l}\text { At the entrance of the } \\
\text { units. }\end{array}$ & $\begin{array}{l}\text { So that symptomatic } \\
\text { people do not enter the } \\
\text { clinic and need to be } \\
\text { directed to an isolated } \\
\text { area. }\end{array}$ & $\begin{array}{l}\text { When people arrive at the units, } \\
\text { questions will be asked about } \\
\text { COVID symptoms and body } \\
\text { temperature measurements. }\end{array}$ & $\begin{array}{l}\text { Absence of } \\
\text { additional cost } \\
\text { through staff } \\
\text { resizing. }\end{array}$ \\
\hline $\begin{array}{l}\text { Oral medication } \\
\text { delivery at home. }\end{array}$ & $\begin{array}{l}\text { Courier of the logistics } \\
\text { team. }\end{array}$ & $\begin{array}{l}\text { At the moment in the } \\
\text { smaller units. }\end{array}$ & $\begin{array}{l}\text { So that this patient } \\
\text { does not need to } \\
\text { attend the unit. }\end{array}$ & $\begin{array}{l}\text { On the date of delivery of the } \\
\text { oral medication, the courier will } \\
\text { deliver to patients' homes. }\end{array}$ & $\begin{array}{l}\text { Professionals' costs } \\
\text { will cover the } \\
\text { deliveries. }\end{array}$ \\
\hline $\begin{array}{l}\text { Training on the } \\
\text { proper use of } \\
\text { personal protective } \\
\text { equipment }\end{array}$ & $\begin{array}{l}\text { Administrative } \\
\text { staff, reception and } \\
\text { assistance, assistance } \\
\text { team (physicians and } \\
\text { multidisciplinary team). }\end{array}$ & Through virtual tool. & $\begin{array}{l}\text { So that the chances } \\
\text { of contamination are } \\
\text { reduced by using } \\
\text { personal protective } \\
\text { equipment in the } \\
\text { wrong way. }\end{array}$ & $\begin{array}{l}\text { Through a meeting through the } \\
\text { ZOOM application and some in } \\
\text { person demonstrating the use, } \\
\text { handling and correct disposal of } \\
\text { personal protective equipment. }\end{array}$ & $\begin{array}{l}\text { Absence of } \\
\text { additional cost. }\end{array}$ \\
\hline
\end{tabular}


Chart 2 (concluded)

\begin{tabular}{|c|c|c|c|c|c|}
\hline What? & Who? & Where? & Why? & How? & How much? \\
\hline $\begin{array}{l}\text { Protection } \\
\text { barrier between } \\
\text { reception staff and } \\
\text { secretaries. }\end{array}$ & $\begin{array}{l}\text { Receptionists and } \\
\text { secretaries. }\end{array}$ & $\begin{array}{l}\text { Transparent acrylic } \\
\text { protection barrier at } \\
\text { reception desks and } \\
\text { desks. }\end{array}$ & $\begin{array}{l}\text { So that there is an } \\
\text { additional barrier } \\
\text { between professionals } \\
\text { and patients and } \\
\text { companions, reducing } \\
\text { the chances of possible } \\
\text { contamination. }\end{array}$ & $\begin{array}{l}\text { Placement of a transparent } \\
\text { acrylic protection barrier at the } \\
\text { reception desk and secretaries. }\end{array}$ & $\begin{array}{l}\text { Cost of acrylics } \\
\text { and labor for } \\
\text { placement. }\end{array}$ \\
\hline $\begin{array}{l}\text { Online classes } \\
\text { on workplace } \\
\text { gymnastics, } \\
\text { relaxation and } \\
\text { activities between } \\
\text { parents and } \\
\text { children. }\end{array}$ & Employees in general. & Online platforms. & $\begin{array}{l}\text { So that stress is reduced } \\
\text { in relation to the period } \\
\text { experienced. }\end{array}$ & $\begin{array}{l}\text { Free and exclusive availability } \\
\text { to company employees } \\
\text { online classes on workplace } \\
\text { gymnastics, relaxation and } \\
\text { activities between parents and } \\
\text { children }\end{array}$ & $\begin{array}{l}\text { No additional } \\
\text { cost, through } \\
\text { partnerships } \\
\text { acquired with } \\
\text { other companies. }\end{array}$ \\
\hline $\begin{array}{l}\text { Increased } \\
\text { time interval } \\
\text { between catheter } \\
\text { maintenance. }\end{array}$ & $\begin{array}{l}\text { Patients with fully } \\
\text { implanted catheters } \\
\text { who are not } \\
\text { undergoing treatment. }\end{array}$ & At the units. & $\begin{array}{l}\text { So that they need to } \\
\text { travel less often to the } \\
\text { units. }\end{array}$ & $\begin{array}{l}\text { Guided patients with catheters } \\
\text { fully implanted who are not } \\
\text { undergoing treatment. }\end{array}$ & $\begin{array}{l}\text { Absence of } \\
\text { additional cost. }\end{array}$ \\
\hline $\begin{array}{l}\text { Withdrawal of } \\
\text { symptomatic } \\
\text { employees until } \\
\text { proof of negative } \\
\text { examination for } \\
\text { COVID } 19 .\end{array}$ & Employees in general. & At the units. & $\begin{array}{l}\text { So that they do not } \\
\text { work with the risk of } \\
\text { contaminating other } \\
\text { people. }\end{array}$ & $\begin{array}{l}\text { Each manager guiding his team } \\
\text { in specific. }\end{array}$ & $\begin{array}{l}\text { Absence of } \\
\text { additional cost. }\end{array}$ \\
\hline
\end{tabular}

Training and guiding the entire team regarding the correct handling and disposal of masks was necessary due to: risk of contamination due to possible incorrect handling with contaminated hands; discomfort caused by wearing the mask; false sense of security, which can lead to less adherence to established prevention measures; risk of transmission by droplets and splashes in the eyes, in case of discontinuation of using masks associated with the eye protector ${ }^{(5-6)}$.

Training with the multidisciplinary team addressed the correct handling of the aprons to avoid contamination during the dressing. Some team members were trained in the swab collection procedure for diagnosing COVID-19. There was ample testing of employees, still without symptoms, which enabled early diagnosis, with removal for treatment of asymptomatic employees with the disease in progress.

In places where the possibility of agglomeration formation was identified, such as in regions close to the elevators and even inside them, markings were placed on the floor to maintain the distance and respect the distance of one meter recommended by the $\mathrm{MoH}$. Reports were placed in the waiting chairs, of patients and companions, intercalating seats so that the distance of 1 meter recommended by the $\mathrm{MoH}$ was maintained ${ }^{(1)}$.

Employees were instructed to report their immediate management as to any sign or symptom of COVID-19, being dismissed until proven by RT-PCR exam for SARS-CoV-2. The withdrawal period is 14 days after the onset of symptoms, or the confirmed or probable case of COVID-19, as directed by $\mathrm{PAHO}^{(6)}$.

Most patients treated at outpatient clinics started to be monitored by telemedicine, following the WHO recommendation ${ }^{(1,7)}$ for assessment, minimizing the need for patients to go to health units to be assessed. The European Society of Oncology Medicine ${ }^{(8)}$ recommends adjustments to routines, suggesting strengthening telemedicine services, reducing clinic visits and changing treatments to subcutaneous or oral therapies instead of intravenously when possible. As for radiotherapy treatments, it is suggested that shorter/accelerated or hypo-fractionated radiation schemes be discussed with radiotherapists, when scientifically justified and suitable for patients.

In cases of initiation of a new treatment or exchange of protocol, nursing consultations started to be carried out in the form of call center by telephone, in line with Resolution 634/2020 of the Federal Nursing Council (Conselho Federal de Enfermagem), which authorized the guidelines and consultations by technological means as a way of fighting the pandemic caused by the new coronavirus ${ }^{(9)}$. Telephone consultation is a facilitating element in therapeutic adherence that provides safer monitoring amidst the COVID-19 pandemic.

To carry out the screening of people who come to the unit, a nursing technician was allocated at the reception of the clinics to measure body temperature with an infrared thermometer. All team members, patients and companions underwent health inquiries regarding the presence of symptoms, such as cough, runny nose, difficulty breathing and fever. The entry and circulation in the units without the use of masks was prohibited, and a surgical mask was offered at the entrance of the clinic to replace that of tissue.

As for the flow of patients who had any symptoms, they were referred to the physician's office, specifically separated to attend to suspected cases of COVID-19. In the case of a companion with symptoms, they were instructed to seek an emergency service for more improved diagnostic evaluation and treatment, making it impossible for them to remain in the unit.

This flow of patients with suspected disease has been streamlined in order to reduce the need for face-to-face interaction between health professionals and patients. After medical evaluation, the patient can be transferred to a hospital unit, be instructed to seek an emergency service by their own means to carry out tests and complementary treatments, or can be directed to the residence, with instructions for home isolation. These conducts are carried out through assessment of the unit's physician or of patients' own assistant physicians, when they are in the unit. 
As for the unit's routine for maintaining fully implanted catheters, patients performed the procedure monthly or every two months, depending on their permeability. With the pandemic, there was an increase in absenteeism, which demanded active search of these patients. There was a change in the orientation for performing this maintenance, extending the period to up to 90 days when the catheter has good permeability, i.e., excellent flow and reflux, considering that this period is not associated with a greater risk of obstruction ${ }^{(10)}$.

Due to fear of contamination, reported during the active search for patients, who were delayed in the maintenance period, some alternative schedules were offered, in periods of reduced circulation in the clinic, considering the risks of postponing the maintenance period, with the increased risk of catheter obstruction.

There was a reduction in attendance at all units, as treatments were reassessed and many were assisted remotely by teleconsultations, which had no impact on the average number of professionals on leave due to COVID-19 suspicion or confirmation, with no need for new hires.

In order to reduce stress due to anxiety and fear in view of the possibility of exposure to the virus by its employees, the company developed partnerships, made available to employees free and exclusively, online classes in gym work, relaxation and activities between parents and children.

Employees were instructed to seek information from secure sources such as $\mathrm{WHO}$ and $\mathrm{MoH}$, minimizing misinformation or counter-information. Mutual support and good relations between co-workers were encouraged, providing a greater sense of belonging and protection, since, with warm and welcoming words, we can touch each other, even without touching ourselves physically.

\section{Study limitations}

Considering the recent discovery of SARS-CoV-2, there is still not a large quantity and quality of scientific productions related to the theme. The constant changes in the approach to the pandemic demand great adaptive capacity in face of the scenario that is being designed daily.

\section{Contributions to nursing}

We hope to contribute to this study so that more professionals and managers use this experience report as a basis for further studies and good practices in caring for patients with hematology and oncology diseases in outpatient treatment.

\section{FINAL CONSIDERATIONS}

We can conclude that although the pandemic has brought a great challenge with practically new discoveries and information on a daily basis, we can always change, adapt, grow, evolve and increasingly provide quality care aimed at cancer patients and professionals involved in care.

The tools used, such as the Ishikawa Diagram and the $5 \mathrm{~W} 2 \mathrm{H}$ tool, were extremely important, as they served as a valuable tool in constructing the measures, making the measures in question more clearly and applicable. It also demonstrates that these management tools function as facilitators for decision-making and reducing contamination by SARS-CoV- 2 .

\section{REFERENCES}

1. Ministério da Saúde (BR). A Gestão de riscos e Governança na Pandemia por Covid-19 no Brasil. [Internet]. Brasília; 2020 [cited 2020 May 30] Available from: https://www.arca.fiocruz.br/bitstream/icict/41452/2/relatorio_cepedes_gestao_riscos_covid19_final.pdf

2. Liang W, Guan W, Chen R, Wang W, Li Jianfu, Xu K, et al. Cancer patients in SARS-CoV-2 infection: a Nationwide analysis in China. Lancet Oncol. 2020;21:335-7. https://doi.org/10.1016/S1470-2045(20)30096-6

3. Zhao N, Shi J, Zeng L,Yang S. Clinical Characteristics and Coping Strategies of Neoplasms with 2019 Novel Coronavirus Infection. Chin J Lung Cancer. 2020; 23(4):261-266. https://doi.org/10.3779/j.issn.1009-3419.2020.102.15

4. Mello MF, Cunha LA, Sila NJ, Araújo AC. A importância da utilização de ferramentas da qualidade como suporte para a melhoria de processo em indústria metal mecânica- um estudo de caso. Exacta. 2017;15(4):63-75. https://doi.org/10.5585/ExactaEP.v15n4.6898

5. Organização Pan-Americana de saúde (OPAS). Uso racional de equipamentos de proteção individual para doença do coronavírus (COVID-19) e considerações durante desabastecimentos graves. Orientação provisória de 6 de abril de 2020[Internet]. Brasília: 2020[cited 2020 Jul 20] Available from: https://iris.paho.org/bitstream/handle/10665.2/52042/OPASBRACOVID1920045_por.pdf?sequence=1\&isAllowed=y

6. Organização Pan-Americana de saúde (OPAS). Folha informativa COVID-19 - Escritório da OPAS e da OMS no Brasil[Internet]. Brasília: 2020[cited 2020 Dec 20]. Available from: https://www.paho.org/pt/covid19

7. Agência Nacional de Vigilância Sanitária. Nota Técnica n 07/2020. Orientações para prevenção e vigilância epidemiológica das infecções por Sars-Cov-2(COVID) dentro dos serviços de saúde [Internet]. Brasília: Agência Nacional de Vigilância Sanitária; 2020 [cited 2020 Jul 20]. Available from: http://portal.anvisa.gov.br/documents/33852/271858/NOTA+T\%C3\%89CNICA+-GIMS-GGTES-ANVISA+N\%C2\%BA+07-2020/ f487f506-1eba-451f-bccd-06b8f1b0fed6

8. European Society for medical oncology (ESMO). Guidelines - Cancer Patient Management during the COVID- 19 Pandemic [Internet]. 2020 [cited 2020 May 20] Available from: https://www.esmo.org/guidelines/cancer-patient-management-during-the-covid-19-pandemic?hit=ehp

9. Conselho Federal de Enfermagem (COFEN). Resolução Cofen n 634/2020. Autoriza a teleconsulta de enfermagem como forma de combate a pandemia provocada pelo novo Coronavírus (Sars-Cov-2). [Internet] Brasília: 2020 [cited 2020 Jul 20]. Available from:http://www.cofen. gov.br/resolucao-cofen-no-0634-2020_78344.html

10. Solinas G, Platini F, Trivellato M, Rigo C, Alabiso O, Galetto AS. Port in oncology practice: 3-monthly locking with normal saline for catheter maintenance, a preliminary report. Acesso J Vasc. 2017;18(4):325-327. https://doi.org/10.5301/jva.5000740 